\title{
Graduate Unemployment in the Context of Skills Shortages, Education and Training: Findings from a Firm Survey
}

\author{
Kalie Pauw \\ Haroon Bhorat \\ Sumayya Goga \\ Liberty Ncube \\ Carlene van der Westhuizen \\ Karel.Pauw@uct.ac.za
}




\section{Abstract}

The paper reflects on the findings from a firm survey conducted among twenty of South Africa's largest firms across a range of sectors. The survey formed part of research conducted by the Development Policy Research Unit on graduate unemployment in South Africa. The firm interviews traversed a range of issues relating, for example, to the schooling and higher education system, the learnership programme and National Skills Development Strategy (NSDS) and the nature of skills shortages and the skills deficit. In turn, a number of detailed long- and short-run policy suggestions emanated from the interviews and background research.

In the context of skills shortages the persistence of unemployment among graduates is puzzling. However, the findings here suggest that reported skills shortages, especially in occupations such engineers, technicians and scientists, are most severe at the middleto senior management level. Graduates do not compete for these positions; in fact, firms generally agree that there are enough graduates available in the economy. Firms do feel, however, that graduates often do not possess the necessary skills and experience to be considered even for entry-level positions. Poor education therefore lies at the heart of the graduate unemployment problem. While on-the-job training in the form of learnerships, implemented in accordance with the NSDS can potentially bridge the skills deficit of graduates, the survey findings rather suggest that this subsidised employment and training programme has not generated above-equilibrium employment in firms.

While short-term interventions may help alleviate immediate skills shortages in the economy, it is clear from this research that a longer-term agenda of radically improving education and training in South Africa is the only sustainable solution to skills shortages and, eventually, the graduate unemployment problem.

\section{Acknowledgement}

This paper is adapted from Chapters 3 and 4 of a Research Report on Graduate Unemployment, which was commissioned by Business Leadership South Africa and funded by Standard Bank. The full report is available from the DPRU on request. Also refere to Working Paper 06/114 in this series.

Development Policy Research Unit Tel: +2721 6505705

Fax: +27216505711
Information about our Working Papers and other published titles are available on our website at: http://www.commerce.uct.ac.za/dprul 


\section{Table of Contents}

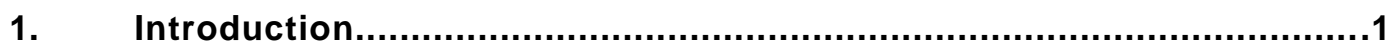

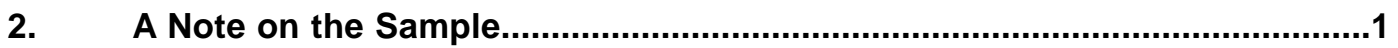

3. Findings from the Firm Survey and Related Research...............................

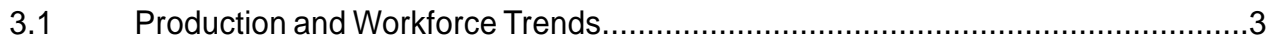

3.2 Recruitment and Talent Management Strategies..............................................5

3.3 Incentive Schemes aimed at Promoting Employment and Training.................10

3.4 Vacancies, Scarce Skills, Education and Training.......................................23

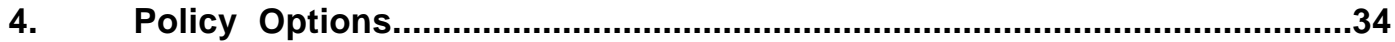

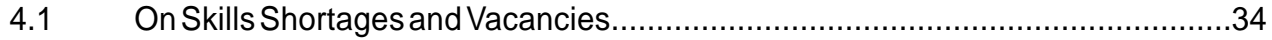

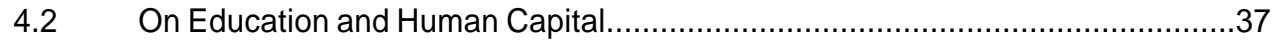

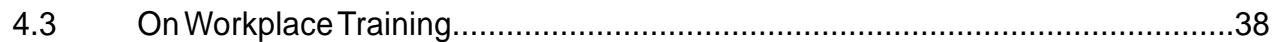

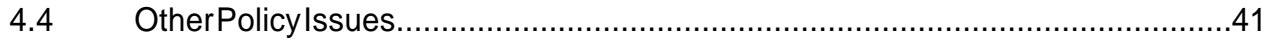

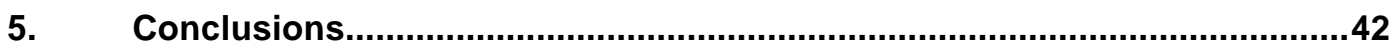

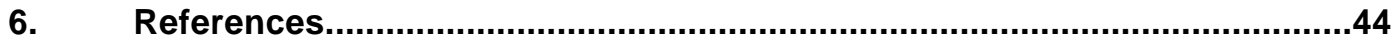




\section{Introduction}

As part of the Development Policy Research Unit's research into Graduate Unemployment (see Working Paper 06/114) a series of interviews with some of South Africa's largest companies, across a range of different sectors, were conducted during February and March of 2006. The interviews, broadly on the graduate unemployment problem, traversed a range of issues relating, for example, to the schooling and higher education system, the learnership programme and National Skills Development Strategy (NSDS) and the nature of skills shortages and the skills deficit. In turn, a number of detailed long- and short-run policy suggestions emanated from the interviews and background research.

\section{A Note on the Sample}

The sample of companies selected for the interviews comprises 20 of South Africa's largest companies, of which 19 are members of Business Leadership. Fourteen of the companies are listed on the JSE, and 13 of these were among the top 40 performing companies as ranked on 10 March 2006 (JSE/Liberty Life, 2006). The companies are spread across a range of economic sectors, with two in the mining sector, nine in the manufacturing sector, one construction company, one company in the wholesale and retail trade sector and two companies in the transport and communication sector. Five major players in the financial services sector were also interviewed. The time constraints imposed on the project did not allow for a larger sample size.

Employment differs significantly across companies, ranging from a workforce of just over 2000 employees to more than 40000 workers. While employment numbers are not available for all the companies, Table 1 provides an indication of the size of the workforce for the companies we do have information for, as well as their share contribution to total employment in the relevant sector in 2005. 
Table 1: Employment by Company and Sector, 2005

\begin{tabular}{|l|l|l|l|}
\hline & $\begin{array}{c}\text { Employment } \\
\text { by Company }\end{array}$ & $\begin{array}{c}\text { Total } \\
\text { Employment } \\
\text { by Sector }\end{array}$ & $\begin{array}{c}\text { \% Share of } \\
\text { Sectoral } \\
\text { Employment }\end{array}$ \\
\hline Mining and Quarrying & & & \\
\hline Company A & 43,214 & & $10.5 \%$ \\
\hline Company B & 31,000 & & $7.5 \%$ \\
\hline Total & 74,214 & 411,077 & $18.1 \%$ \\
\hline & & & \\
\hline Manufacturing & & & \\
\hline Company C & 2,983 & & $0.2 \%$ \\
\hline Company D & 24,737 & & $1.4 \%$ \\
\hline Company E & 2,010 & & $0.1 \%$ \\
\hline Company F & 10,441 & & $0.6 \%$ \\
\hline Company G & 5,320 & & $0.3 \%$ \\
\hline Company H & 3,000 & & $0.2 \%$ \\
\hline Company I & 4,000 & & $0.2 \%$ \\
\hline Total & 52,491 & $1,706,458$ & $3.1 \%$ \\
\hline & & & \\
\hline Construction & & & \\
\hline Company J & 24,904 & & $2.7 \%$ \\
\hline Total & 24,904 & 934,971 & $2.7 \%$ \\
\hline & & & \\
\hline $\begin{array}{l}\text { Transport, Storage and } \\
\text { Communication }\end{array}$ & & & \\
\hline Company K & 26,133 & & \\
\hline Company L & 10,059 & & $1.6 \%$ \\
\hline Total & 36,192 & 615,743 & $5.9 \%$ \\
\hline Financial and Business Services & & & \\
\hline Company M & 2,675 & & \\
\hline Company N & 36,156 & & \\
\hline Company O & 5,264 & & \\
\hline Total & 44,095 & & \\
\hline & & & \\
\hline
\end{tabular}

Source: LFS 2005: 2 (SSA, Various); Company interviews and annual reports;

Notes: Employment includes permanent, contract as well as temporary workers

The two mining companies accounted for more than 18 per cent of employment in the mining and quarrying sector in 2005. Seven of the manufacturing companies contributed 3.1 per cent to the total employment in their sector, while the construction company accounts for 2.7 per cent of sectoral employment. Almost 6 per cent of the workers in the Transport and Communication industry were employed by the two companies that we interviewed. The three financial services institutions that we have information for employed 3.4 per cent of the workers in the financial and business service sector. 


\section{Findings from the Firm Survey and Related Research}

\subsection{Production and Workforce Trends}

The introductory segment of the interviews covered general issues around past company performance and future expectations, and how these have impacted on, or are likely to impact on employment in the future. In particular, companies were asked about changes in the size and composition of their workforces. Evidence presented in Section 2 suggests that South African firms are increasing the skills intensity of production as a result of the adoptions of technologically advanced production techniques in an effort to become more competitive globally. This often leads to a decrease in the size of the workforce while at the same time altering the composition of the workforce (ratio of skilled versus unskilled workers). The introductory questions were therefore aimed at finding out whether such trends were also visible in the small sample of large firms interviewed. However, at the same time the South African economy is entering a boom phase, which implies that some firms may actually expect to expand their production capacities and hence employment numbers.

The firms interviewed typically have complex corporate structures and are often involved in mergers or new acquisitions, selling of subsidiaries and outsourcing of activities. The corporate landscape has also changed dramatically in the last few years with companies entering into Black Economic Empowerment (BEE) deals. Such corporate transactions may have important employment effects for the company concerned (as reflected in their payroll), but the indirect employment effects elsewhere in the economy may in fact negate the net employment effect. As a result it is sometimes difficult to discern employment trends. However, the general industry-specific trends seem to concur with those of the economy. In short, the past decade or more has shown a decline in the importance of the primary sectors in the economy and a shift towards the more skill-intensive secondary (manufacturing) and tertiary (services) sectors. Firms themselves have also typically become more skills intensive. Below, we briefly report on some of the industry and firm-specific findings with regards to growth expectations and employment trends.

The mining companies generally agree that the mining industry is unlikely to grow in the future, at least not within the domestic economy. As such, the industry is unlikely to maintain its share of employment as the labour force grows over time - a trend that has in fact been visible for some time and can be expected from developing economies. The gold mining industry in particular is at best stable, but potentially a declining one, despite recent hikes in the gold price. The large mining companies in South Africa are multinationals and at present, company growth is driven mainly by expansion into overseas markets, with no significant employment impact domestically in South Africa.

As far as company growth and past and future employment trends in manufacturing are concerned, most companies plan to expand production, both domestically and internationally. However, very often increased domestic output is associated with higher labour productivity 
and improved production techniques rather than increased employment levels. While few firms are explicitly reducing their workforce sizes through layoffs, many are becoming 'leaner' in the long run by recruiting at a rate that is below the natural attrition rate (resignations and retirement) of the workforce. Increased production efficiency is also typically associated with increased skills intensity of the workforce. However, this trend of downsizing or 'rightsizing' is likely to be something of the past. It had much to do with inefficiencies in production that had to be dealt with. In many instances large and ineffective staff structures were inherited from the past, caused in part by subsidisation and years of economic isolation. The current economic recovery can, however, reverse the trends of downsizing, especially if the manufacturing sector is able to exploit opportunities. Some firms hinted at plans to expand production capacity, especially in the light of announcements by government of large-scale investments in public infrastructure. ${ }^{1}$ Such an increase in, for example, the number of plants a firm owns and operates, is likely to go hand in hand with increased employment levels despite continuing efforts by firms to become more efficient in production. ${ }^{2}$ The combined effects of skills intensification and capacity expansion imply that key manufacturing skills, e.g. artisans, technicians, scientists and engineers will become even more important in the near future (see discussions in section 3.4).

Firms in the services sector generally report that favourable economic conditions have meant an increase in business and employment opportunities. Firms in the wholesale and retail trade sector have experienced a boom phase and report significant increases in sales, the number of retail outlets and employment levels. Favourable economic conditions during a period of low interest and inflation rates have led to strong growth in consumption expenditure by households in the last five to ten years. The financial services industry has also benefited from increased economic activity and expansion into non-traditional markets. ${ }^{3}$ As a result employment levels in banking, auditing and insurance firms have been on the rise. There was one exception to this, with one of the insurance firms reporting a decline in employment in the last three to five years. However, this was related to the net employment effects of mergers, acquisitions and outsourcing of non-core business processes. The transport and communications sector is highly monopolised. As competition barriers are being removed the firms are driving efficiency and restructuring inefficient staff structures, which have generally led to a decline in employment levels.

1 According to the 2005 Medium Term Budget Policy Statement (National Treasury, 2005) public sector investment is set to rise from its current level of approximately 6 per cent of GDP to 8 per cent of GDP. This implies that government's capital budget will rise by between 15 per cent and 20 per cent per annum (ASGISA, 2006).

2 Few firms were willing to reveal specific plans to expand capacity given the sensitive nature of such information. However, some firms have hinted at the potential impact of government's plans to increase public investments (see footnote 1).

3 This includes mostly remote rural areas and informal markets that were previously not serviced by the banking industry. 
In summary the broad industry trends suggest that the services sector will remain the fastest growing sector. Financial management and accounting skills are important and enrolment in these areas has to be encouraged. However, the manufacturing sector should not be ignored. Skills intensification and capacity expansion linked to government's plans to invest heavily in infrastructure also implies that the current skills shortages in technical occupations such as artisans, engineers and technicians will become even more critical.

\subsection{Recruitment and Talent Management Strategies}

\subsubsection{Recruitment Philosophies}

The recruitment processes and strategies vary greatly between different types of firms. In particular, two main approaches exist. The first is commonly known as the 'pipeline' strategy, which entails a strong focus on the recruitment of young people who start at entry-level positions and are groomed and trained for middle- to senior management positions within the firm. Most of the firms (95 per cent) interviewed base their recruitment strategies on such a pipeline strategy. For most of these firms the recruitment process is a core business function, with bursary schemes, training initiatives, graduate recruitment drives and general recruitment all linked explicitly to the current or future business needs of the firm. However, few of the firms interviewed felt that their pipeline strategies are working in the sense that most vacancies arising at middle- to senior management levels are filled internally. In fact, many firms end up spending a large amount of resources on recruitment and headhunting of people with experience to fill vacancies at the upper end of the pipeline.

The second approach is that of only hiring people with experience. This implies that higher salaries are offered, but limited training is required given the person's past experience. The choice between employing recent graduates or matriculants into entry-level positions as opposed to employing more experienced workers is a difficult one to make. Despite the fact that most firms adhere to the pipeline strategy quite a number of firms nevertheless feel that experienced workers are more attractive than recent graduates from a recruitment point of view. Graduates and matriculants need substantial investments in training before they become assets to the companies. At the same time young people are highly mobile and the risk of losing a young trainee to a competitor shortly after completion of training is high. Yet, only a single manufacturing firm was very explicit about the fact that they did not employ recent graduates at all as they value experience more and are willing to pay a premium to attract skills. ${ }^{4}$

$4 \quad$ This is perhaps sample-specific. Typically large firms are in a better position, financially, to spend large amounts of money on training and staff development. They are also more willing and able to take the 'risks' associated with the pipeline strategy. 
From a national human resource development point of view it is crucial that all firms buy into the pipeline strategy. For this to happen incentives need to be created to increase the absorption of graduates or young people, while firms' investments in training and development of young recruits should be protected. The learnership programme is one such incentive system. The fact that the majority of firms interviewed are forced to recruit experienced workers externally when vacancies arise at middle to senior management level, often at a large cost to the company, is indicative of the failure of the pipeline strategies of many firms. The cost to the company is often inflated due to exorbitant headhunting fees of employment agencies. The problem is exacerbated, of course, by poaching and headhunting due to the ongoing 'war for talent' in South Africa.

Recently steps were taken to simplify the immigration process for foreign workers with key skills. This reflects the severity of the scarce skills problem in South Africa (see section 4.1.1). However, such initiatives have to be seen as short-term measures aimed at relieving immediate shortages in the market, and should only be considered in cases where skills shortages are hampering company growth. The fact that companies regard experienced workers, whether foreign or local, as more attractive than inexperienced graduates is worrying.

\subsubsection{Graduate Recruitment}

Recruitment drives or recruitment exhibitions on campuses are potentially very important to both employers and employees. From a firm's perspective they represent an opportunity to market the firm as a preferred employer, which may attract high-calibre jobseekers. From the students point of view they provide information, open up opportunities and options, while also shaping perceptions and expectations of students about the workplace. ${ }^{5}$

The use of recruitment drives at campuses generally depends on the firms' preference for this type of recruitment strategy. Recruitment drives are often very expensive, especially when it involves campus visits with exhibits and presentations, and on-campus screening and interviews. As a result, on-campus recruitment drives are often only used by large firms that employ large numbers of graduates annually as a recruitment channel. ${ }^{6}$ For firms that only take on a limited number of graduates annually, recruitment drives are viewed as too expensive.

From the interviews it became clear that the majority of firms that make use of recruitment drives prefer to visit only specific institutions, with most firms being fairly explicit about the fact that they do not approach historically Black institutions. A variety of reasons was listed:

5 There is of course also the danger of 'too much information', especially with the Internet becoming an important marketing tool for firms.

6 The majority of firms interviewed make use of on-campus recruitment drives. 
- Most importantly or worrying perhaps, are companies' concerns about the quality of education at these institutions. When firms invest large amounts of money in recruitment drives they at least expect a return in the form of an acceptable (quality education and good grades) number of potential recruits. This is often not the case at historically Black institutions.

- Some firms also felt that students at historically Black institutions are typically not exposed to many such corporate recruitment drives, and are, therefore, sometimes overwhelmed and unable to deal with the interview process in a mature way. Consequently, the students are not highly successful in terms of being short-listed. This relates to the problem of underdeveloped soft skills (communication skills, writing skills etc.) among many young Black graduates in South Africa.

- Many of the manufacturing firms indicated that they do not approach historically Black institutions since they do not offer courses in areas where they recruit, e.g. engineering. Recruitment drives at historically Black institutions simply do not produce the number of suitably qualified candidates to make the expense worthwhile.

- Given increased enrolment numbers of Black students at historically White institutions most firms indicated that they manage to find enough employment equity candidates by only visiting the historically White institutions.

- Adding to firms' reluctance to visit historically Black institutions is the inability of these institutions to facilitate recruitment drives. Many of these institutions have poor infrastructures in terms of facilitating graduate recruitment drives. The infrastructure required to facilitate recruitment programmes includes well-functioning recruitment placement offices, trained and committed staff, suitable venues for talks, presentations and exhibitions, and media (radio, student newspapers etc.) on campus. ${ }^{7}$

The low probabilities of students from historically Black institutions of finding employment after graduation are possibly linked to firms' unwillingness to invest in recruitment drives at these institutions. Firms can never be forced to visit specific institutions. It remains a business decision. Tertiary institutions need to realise the importance of facilitating the process of bringing together prospective employers and employees, especially if this can increase the success of students in finding employment opportunities. It is crucial for historically Black institutions to realise that their quality is also measured by their graduates' success in securing employment, and that any efforts towards improving their chances of finding employment will reflect positively on the institution. The career prospects of students at historically Black

7 This was a comment not restricted to historically Black institutions. Some historically White institutions were also unhelpful in facilitating recruitment on campuses. 
institutions will be further enhanced by improving the quality of teaching at these institutions. Alternatively, if quality is on par then these institutions have to realise the importance of using proper marketing strategies for their institution, to alter the perceptions of employers.

\subsubsection{Bursary Schemes}

About 65 per cent of firms interviewed link their graduate recruitment processes to bursary schemes. These are generally linked to university education, but in some instances bursaries are also offered for studies at universities of technology or other technical institutions. The number of bursars taken on varies widely between firms, but is largely linked to the annual intake of graduates at the firm. Some firms, however, offer fewer bursaries annually than the planned intake and supplement the annual intake of graduates during graduate recruitment drives on campuses. Others offer more bursaries than the planned intake, in which case the expenditure on the bursary is seen as a corporate social investment in education.

Generally firms are very positive about their bursary schemes for a number of reasons:

- They ensure to a large extent that the targeted annual intake of graduates is reached. They also allow firms to plan ahead and ensure that employment equity targets will be met in the future by enrolling the right mix of students.

- The firm can become involved more directly in the education of the student in the sense that they can provide academic support and guidance as to subject choice. Some of the firms that run large bursary schemes offer additional guidance in terms of subject choice, tutorials and study support.

- Firms can offer relevant practical experience to bursary holders by creating opportunities for vacation work. This not only supplements students' incomes, but prepares students for the workplace and reduces the training requirement of students once they become employed full-time.

- All these benefits come at a fairly low risk to the company. Most bursaries are offered on condition that bursars have to work for the company for a set number of years, usually linked to the time of sponsored study. If the student is unwilling to work for the company at completion of his or her studies the bursary often has to be paid back with interest. Such conditions are seldom attached to normal training offered at the workplace.

\subsubsection{Employment Equity and the 'War for Talent'}

Sectoral BEE (and more recently BBBEE) charters typically dictate employment equity targets for industries. However, it can be argued that employment equity requirements have biased remuneration packages of previously disadvantaged individuals with desired skills and experience upwards. As far as the intake of previously disadvantaged graduates is concerned 
firms generally feel that there is no shortage of graduates with suitable qualifications. However, when it comes to Black students with good quality qualifications and above average grades, in certain study areas in particular, firms are experiencing shortages.

Manufacturing firms found it especially difficult to find good quality Black candidates with engineering, science and information technology qualifications. While equity targets are more easily reached in the finance and business sectors, given relatively large enrolment of Black students in commerce disciplines, Black students with good finance and accountancy grades are still hard to come by. This is especially true for African Black students: firms indicate that they generally have less trouble finding Indian and Coloured students. The poor performance and high failure rate of Black students at tertiary institutions has become somewhat of a national concern and has led to the a joint research initiative between the Association for Black Empowerment in Higher Education (ABEHE) and the Human Sciences Research Council (HSRC) on the matter.

Another concern raised by firms relates to soft skills and workplace readiness, specifically among students from historically Black institutions. For many the transition from poor quality schooling to tertiary institutions is a difficult one. The transition from tertiary institutions to the workplace is even more challenging. Firms cite poor soft skills, such as (English) communication skills, as a key shortcoming of students from historically Black institutions. These institutions also seldom offer the type of work experience opportunities that can be found at historically White universities, e.g. representation on student bodies, administrative or academic assistant positions in university departments, and so on. However menial these tasks, they provide some form of basic experience to students in dealing with administrative issues and communicating optimally at the workplace. Firms find that, generally speaking, students who come from historically White institutions, both Black and White, are better prepared for the workplace both in terms of soft skills and work experience, and therefore are better able to adapt to corporate environments. Although there is no hard evidence for this, it is clear that this differential signalling is in part a function of students at historically Black institutions as opposed to historically White institutions, irrespective of race, having experienced distinctly lower quality schooling relative to their counterparts at historically White institutions.

The high mobility of young Black graduates is further cause for concern given employment equity targets and the war for talent in this country. Most firms report a higher than average turnover rate for young Black workers, especially those with sought-after qualifications such as engineering and science degrees. Often, high calibre Black employees with scarce skills do not stay in positions long enough to gain the necessary experience before being offered more lucrative positions by rival firms. Poaching of this nature comes at a serious cost to the economy, both in terms of recruitment costs (it can easily cost an employer up to R80 000 to headhunt a prospective employee) and skills lost to specific industries when people move between industries. One of the mining firms for example, noted that many mine managers 
are being poached by the finance industry for their good managerial skills. However, more importantly, high mobility, especially early on in a career, can also be harmful to the individual who never fully realises his or her potential. The long run risk is that these individuals become unattractive to prospective employers due to the perceived risk of employing them and investing in their training. In response to high turnover rates many firms have aggressive retention strategies in place.

Given the size of the firms interviewed, many are able to offer remuneration packages above the industry averages, which to some extent reduce labour turnover rates. Although this is a successful way of reducing labour turnover by countering poaching, it sends the wrong signals. As a result some firms feel that certain 'unfair' recruitment practices should be regulated. Also, talent management should become a key personnel management function in firms and young appointees should be educated about the dangers of changing jobs too regularly.

\subsubsection{Graduate Expectations}

Most firms indicated that the expectations of graduates, particularly university graduates, are too high. Employers, however, feel that the return to employing a graduate is low, given that graduates require substantial on-the-job training before they provide optimal returns. In addition, many firms indicated that these expectations are unjustified, particularly because of the limited experiential training of graduates. Some firms also indicated that graduates expect their qualifications to open doors at middle management level and are often unwilling or unhappy to start at entry-level. Firms feel that it is necessary for graduates to have a more realistic view of what they can offer and what to expect from their first jobs.

In addition, as argued in the previous section, current labour market requirements have biased remuneration packages upwards. However, some firms feel that the chronic shortages of Black university graduates are starting to subside and remuneration priced more realistically. Yet many graduates still expect high start-up packages.

\subsection{Incentive Schemes aimed at Promoting Employment and Training}

\subsubsection{The National Skills Development Strategy}

The National Skills Development Strategy (NSDS) was launched in February 2001 with the aim of transforming education and training in South Africa by improving both the quality and quantity of training. The responsibility of implementing the NSDS rests with the National Skills Fund (NSF) and the Sector Education and Training Authorities (SETAs). Under the Skills Development Act of 1998 (Republic of South Africa, 1998), 25 SETAs were established in March 2000. ${ }^{8}$ The Skills Development Levies Act of 1999 (Republic of South Africa, 1999)

$8 \quad$ There are currently 23 SETAs due to the merger of some of the SETAs in 2005. 
requires that employers with an annual payroll of greater than R250 000 pay 1 per cent of the value of their payroll to the South African Revenue Services (SARS). ${ }^{9}$ Of the levy, 80 per cent is transferred to the relevant SETA and the remaining 20 per cent is transferred to the NSF. Employers can claim back a maximum of 50 per cent of the original 100 per cent levy in the form of mandatory grants and 20 per cent in the form of discretionary grants. The remaining 10 per cent is retained by the SETA for administration.

One of the functions of SETAs is to develop and register learnership programmes. Learnerships are specifically aimed at assisting new entrants into employment by providing them with skills and improving their chances of finding or creating work. The learnership system is derived from the apprenticeship system; while in countries like the UK, Australia and Germany these retooled apprenticeships became known as 'Modern Apprenticeships'; in South Africa they became known as learnerships (Smith et al., 2005: 540). The purpose of learnerships is threefold: to provide workplace learning by an accredited training provider, to ensure the link between structured learning and work experience, and to ensure that training culminates in a nationally recognised qualification. The qualification obtained via a learnership is registered on the National Qualifications Framework (NQF) by the South African Qualifications Authority (SAQA). The building blocks of learnerships are unit standards. Employers implementing learnership agreements can claim back discretionary grants from the relevant SETA, and in addition are entitled to tax breaks. These incentives are typically higher for unemployed learners.

By March 2005, a total number of 109647 unemployed people below the age of 35 had entered into learnership/apprentice agreements, well above the target of 80000 set out in the NSDS. Figure 1 shows the rapid growth in the number of learners between 2002/3 and 2004/5. However, how many people have successfully completed their learnerships programmes and found employment is unclear (employers are not obliged to employ learners post-learnership), although Jennings et al (2004) (cited in Department of Labour, 2006a) and Smith et al (2005) give some indication of the trends. There has also been much concern about the functioning and effectiveness of SETAs and the learnership system, as well as the perceived quality of learnership programmes in some cases given that SETAs have received substantial funding through collection of skills levies as well as the NSF.

$9 \quad$ Employers paying annual remuneration of less than R500 000 are exempt from skills development levies from 1 August 2005. 


\section{Figure 1: Total Number of Learners on Learnership Programmes}

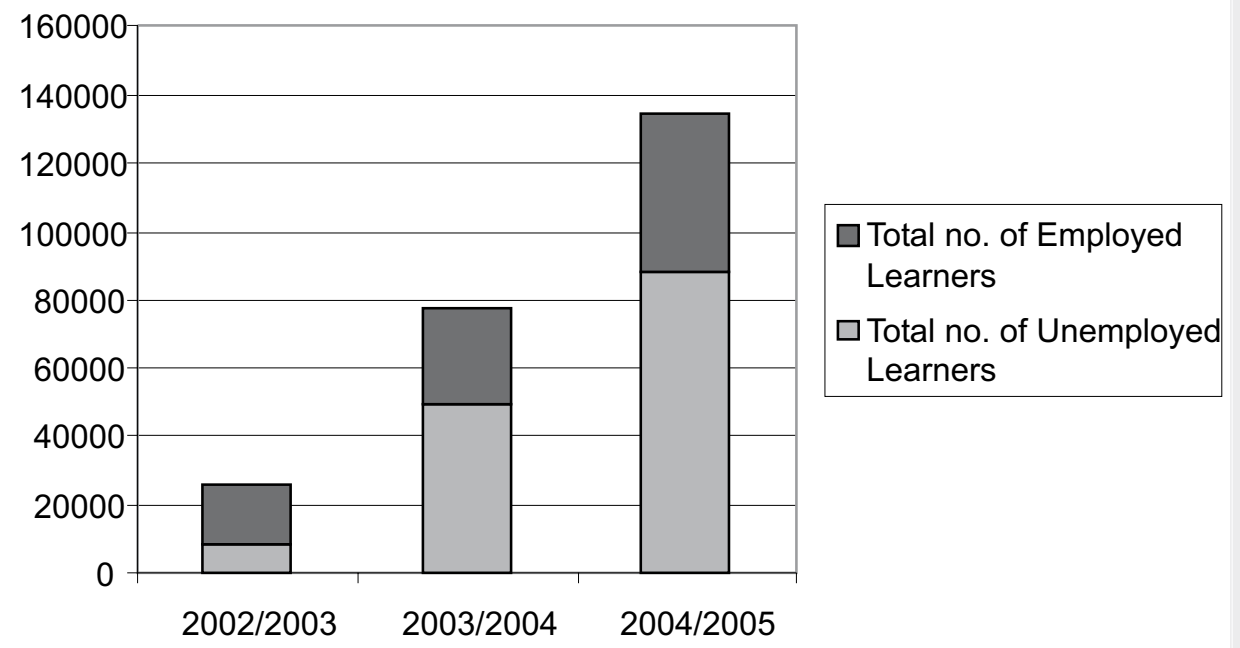

Source: Department of Labour $(2005,2006 a)$

The Skills Development Act of 1998 effectively repealed the Manpower Training Act of 1981 (Republic of South Africa, 1981), which governed apprenticeships. However, schedule two in the Skills Development Act made provision for those sections in the Manpower Training Act pertaining to apprenticeships to remain in force until the Minister repealed them by notice in the Government Gazette. The Act, therefore, seemed to suggest that apprenticeships were being phased out and replaced with learnerships. Adding to these suspicions is the fact that learnerships have a much broader scope in terms of the coverage of occupations and thus in a sense encompass apprenticeships (see section 3.4 for more):

- Learnerships are period bound and linked to specific SAQA registered qualifications (NQF recognised). The scope of coverage is for all possible qualifications (approximately 25000 ).

- Apprenticeships are also linked to a qualification, but these are not necessarily SAQA registered. Apprenticeships are further linked specifically to designated artisan trades (approximately 500). The fact that apprenticeships are not SAQA accredited should not be seen as a distinct disadvantage of apprenticeships. SAQA accreditation implies basically that qualifications are aligned to the NQF, whereas apprenticeship qualifications are not necessarily (although in reality they are equivalent to NQF 1 to 4 levels). The SAQA qualifications are also transferable between industries, which makes it perhaps more attractive to jobseekers. However, apprenticeship qualifications are also nationally (and sometimes internationally) recognised, but often only within the specific industry in which they were obtained. 


\subsubsection{Firm Responses to Learnerships, Apprenticeships and Workplace Training}

During the interviews firms were asked about the effectiveness of the learnership system in absorbing more graduates and/or young unemployed people. Respondents were also asked to talk about workplace training in general and comment on the incentive systems that in are place. The focus was mostly on learnerships, although apprenticeships are still favoured in some of the manufacturing sector firms.

As noted in the preceding section a large number of learnerships have been registered and many people have been put onto learnerships during the last few years. Learnerships have the dual objective of improving the skills of the general workforce and at the same time increasing employment directly (in the sense that the grants act as an employment subsidy) or indirectly (in that learners generally become more employable and are thus employed on completion of the learnership). Learnerships are generally targeted at both the employed and unemployed, although the grants available for unemployed learners are higher. About two-thirds of learners in South Africa are officially classified as unemployed learners (see Figure 1 in Appendix A, and Smith et al. (2005) for more).

However, indications from our interviews are that these represent people that the firms would have hired anyway. As such learnership grants are in a sense a windfall gain as firms probably would have trained these workers anyway. Although harsh, critics may see this as a failure of the learnerships in its objective of increasing employment levels over and above what the employment level would have been in the absence of the incentive system. Put differently, the learnership programme on current evidence has done little to increase employment above the existing market equilibrium level of employment.

The idea of the learnership system was that some firms would utilise economies of scale and offer workplace training to more learners than they could or wanted to absorb themselves. However, it appears as if incentives are not high enough as very few firms train 'for the market'. Most firms prefer to link learnerships to their actual recruitment strategies with the intention of employing all learners upon completion. This obviously explains why there is no net employment effect over and above what normal absorption would have been. This is also understandable; as one respondent said, he hates the idea of offering training to learners, but then having to turn them away once they complete the training. Not only is it stressful to learners as they have to look for new employment opportunities, but the firms providing the workplace training are left to deal with the disappointment.

A policy option that may be considered is the idea of a marginal subsidy. This involves offering higher subsidies to firms who increase the intake of learners over and above the intake of the previous year. As discussed in section 3.3.3 firms suggested they would only consider increasing the number of learners if all costs were covered. This includes the financial costs associated with training provision, as well as the administrative burden associated with 
implementing and running the learnership programme (see Box 3 for more information).

Evidence presented by Smith et al. (2005) does seem to indicate that the tax breaks are acting as an incentive to at least enrol staff members in formal training programmes: about 75 per cent of respondents in a firm survey conducted by these authors indicated that they were involved in learnerships because of the tax incentives. Thus, although net employment levels are perhaps not increased by the learnership system, more people are formally trained and acquire SAQA-recognised qualifications. Firms are generally very positive about the impact learnerships have on skills at the firm level, which certainly implies that learnerships are successful in achieving the primary goal of improving skills of the workforce.

Some general comments by respondents that are relevant in this regard include the following:

- Some firms partake in the process because of their industry's BEE charter prescriptions and the BEE points that they can earn for offering learnerships. Many respondents suggested that learnerships are too expensive for small firms to implement. One solution is for large companies to offer learnerships that are linked to employment opportunities at smaller firms. These could, for example, include small firms that are linked to the large firm as a supplier (upstream) or client (downstream). A number of respondents suggested that much greater collaboration is needed between large and small firms, as proper utilisation of capacity at training facilities at large firms could lead to a win-win situation for all.

- Learnerships are not the only solution to creating employment and bridging the skills deficit. It is also not a system that suits all industry types. In some industries apprenticeships with a more practical focus may perhaps work better (artisans, technologists) while in other instances a more academic approach is perhaps preferred (accounting article clerks). Often firms would prefer to offer relevant practical training that is not necessarily linked to a SAQA recognised academic qualification. This idea is explored in more detail in section 3.4.

- Bursary schemes are utilised by many larger firms either as a corporate social investment or as core part of the recruitment process. The latter should be encouraged and perhaps even subsidised by the state as an alternative to learnerships or wage subsidies. If bursars are expected to do vacation work as part of the requirements of the bursary contract it becomes very similar to a learnership scheme, but potentially less costly since the academic assessment takes place outside the firm at the educational institution. Such bursary schemes should preferably be funded over and above existing state bursary schemes. One possibility is to finance and administer this funding through the National Skills Fund (NSF) contributions made by firms as part of the skills levy paid to SETAs. The NSF is already involved in education funding in terms of its National Students 


\subsubsection{Learnerships and Graduate Absorption}

Learnerships are generally not targeted at graduates in the pure sense of the word, i.e. university or university of technology graduates. During the interviews firms suggested that graduates are often reluctant to enrol for learnerships since further training of this nature is 'beneath them'. There is a perception that learnerships have simply replaced workplace training based on the apprenticeship system, which was specifically targeted at artisans and the lower NQF level (or equivalent) qualifications. As a result learnerships have a kind of a 'blue collar worker' label. Yet, the system is designed to include workplace training and education at all NQF levels, which includes even post-graduate qualifications. ${ }^{10}$

This suggests that learnerships at present are not necessarily geared towards relieving the graduate unemployment problem per se. Yet, they are potentially able to address the matter, particularly with regards to the following:

- Many graduates lack soft skills and are not workplace ready when they start their careers in the corporate sector. In fact, this was highlighted as a reason why many graduate are unsuccessful already in the recruitment phase (see section 3.2). However, some firms have started using learnerships successfully as a way to bridge the 'soft skills deficit' and narrow the gap between the workplace environment and student life. Various soft skills learnership programmes are available, for example the Mentoring Programme (NQF 3 to 5 covered) offered by the Reach Africa Group (a training provider) in conjunction with the Services SETA (see www.reachafrica@ iafrica.com).

- Another problem frequently raised by employers was the fact that students often graduate with inappropriate degrees. Firms frequently demand people with financial backgrounds, or more technical qualifications such as science and engineering. One of the auditing firms interviewed said they were in the process of developing a learnership based on similar principles as the so-called CA conversion course at the University of Cape Town. This is a one-year course that allows graduates with non-commerce first degrees to convert to a B.Com. (Accounting) degree within one year, enabling them to then apply for article clerk positions at auditing firms. Such a programme can easily be implemented as a learnership at a firm, with the university as the training provider.

- $\quad$ Another way in which learnerships can be used to absorb more graduates with less appropriate qualifications is in the Business Process Outsourcing (BPO) sector (see Box 1). Many firms, including telecommunications and financial and business services firms, are enrolling graduates with non-technical qualifications, but with some IT skills in call centre learnerships where they quickly learn basic business and 
communication skills pertaining to the specific call centre work that they perform. This presents a wonderful opportunity to graduates to enter the workplace, gain valuable experience and move on to better opportunities. 


\section{Box 1: Business Process Outsourcing, Graduate Recruitment and Learnerships}

Business Processing Outsourcing (BPO) refers to the strategic business tool whereby firms outsource noncore business processes to service providers who are often able to perform the relevant tasks at a lower cost given economies of scale, specialisation and cost structures (e.g. lower wages). The Government has identified the BPO sector (together with the tourism sector) as a priority sector for its Accelerated Shared Growth Initiative (ASGISA). The sector's high labour intensity and rapid worldwide growth makes it an ideal sector for job creation, while it also presents various opportunities for broad-based BEE and small business development (see ASGISA, 2006).

The South African Contact Centre Community (SACCCOM) is an NGO with developmental objectives and a view to promote the growth and development of the contact centre and BPO sector in South Africa. In particular, this NGO promotes outsourcing as an option to domestic firms and supports firms wishing to enter the market as service providers (e.g. telecommunications firms, ICT firms, auditing firms etc.). SACCCOM also promotes South Africa internationally as a preferred offshore location for foreign firms.

South Africa's offshore call centre industry is growing and is well positioned to exploit current opportunities given its multiple urban centres and first-world infrastructure. The McKinsey management consultancy group's study on the viability of the BPO sector shows that the English speaking global market is expected to grow about five or six fold over the next 3 years, with 40 to 50 per cent of the growth accounted for by the banking and insurance business that frequently make use of BPO. The study argues that an additional 3 million jobs will be created worldwide in the BPO sector, of which, 200000 to 500000 jobs will be contested by South Africa and its direct competitors. If South Africa is able to successfully exploit this opportunity the country stands to create between 65000 and 100000 jobs, attracting $\$ 90$ to $\$ 175$ million in FDI in the process.

The sector employs many young people, typically aged between 18 and 35 . Specific requirements usually include fluency in English and computer literacy, depending on the service. The majority of people in the BPO sector are school leavers or matriculants, who typically have a long-term view of employment and as such investing in training of matriculants is seen as a fairly safe investment from the firms' point of view. However, graduates are also employed. Graduates, although more mobile (they generally see this sector as a stepping stone into the market), are often targeted to fill middle to senior management positions in BPO sector firms after completing basic training. Compared to matriculants, graduates require less training and move faster up the job ladder. However, the industry faces the challenge of promoting the BPO sector as an option to graduates since starting salaries are low and the industry is perhaps not seen as glamorous. According to SACCCOM they intend promoting the BPO as an employment option to students at campus recruitment drives.

Out of several companies interviewed at least five have implemented learnerships to train call centre staff. One of the auditing companies has identified BPO as a major growth sector and they have already expanded their services in this sector (outsourcing accounting and human resource management services). As such they run various learnerships to train people for call centre work and on-line support services in the areas of accounting and human resources (SAP based software). Various other financial institutions, especially insurance companies, make extensive use of call centres to support their large client bases, and training is often offered in the form of learnerships. 


\subsubsection{Administration and Costs of Learnerships}

The complex bureaucratic processes surrounding the establishment of learnership programmes and the enrolment and assessment of learners were frequently raised as a major barrier to expanding learnerships. In some instances the process of setting up and registering learnerships is seen as too cumbersome to make it a worthwhile exercise. At the SETA level, mismanagement, inefficiencies and high staff turnover rates were some of the problems mentioned. This was a common sentiment across all firms. The few firms that felt the process was fairly straightforward typically have representation on the SETA boards, which implies they have better knowledge of the procedures. In addition, the sample of firms interviewed represent those that typically have the resources and capacity to deal with SETA problems as compared to smaller firms who do not have the resources and capacity, yet many of the firms find the SETA environment a difficult environment in which to function, with one firm going as far as to call the process a 'nightmare'.

Incentives for the private sector to register learnerships come in the form of tax breaks and learnership grants. Companies who take on previously unemployed learners are entitled to a tax break of a maximum of R50 000 per learner, R25 000 claimable in the year of enrolment and R25 000 claimable in the year of completion. For those that take on employed learners, 70 per cent of the initial R25 000 may be claimed. From 1 March 2006, the maximum initial allowances for existing employees increased to R20 000 (up from R17 500) and to R30 000 for new employees (up from R25 000). The maximum allowance upon the completion of the learnership increased from R25 000 to R30 000. ${ }^{11}$

The other incentive offered is a grant for putting people onto learnerships. The actual size of the grant is determined by the SETAs. The grants are managed and disbursed by the SETAs, the amount depending on the level of complexity of the learnership, the input costs, the difficulty associated with convincing employers to take on learners, etc. The grant is meant to cover the learner allowance, as well as the course fees for the training and other associated costs. The grants for taking unemployed people onto learnerships are typically higher than for taking on employed people.

Firms generally indicated that the incentives were well below aggregate actual direct costs borne by firms, which include stipends, training materials and tuition costs. When adding the indirect costs, such as staff (administrative) and infrastructural requirements the net cost per learner becomes substantial. Few firms could provide accurate estimates of the net cost of learnerships. Crude estimates of the net operating cost per learner per year were in the region of R35 000 . When also accounting for staff and infrastructure

11 More favourable allowances were also introduced to promote the enrolment of disabled learners (National Treasury, 2006a). 
requirements, the actual budget outlay increased to about R150 000 per learner per year. ${ }^{12}$

The majority of firms interviewed indicated that they could only expand their learnership programmes if the grants were increased to such an extent that all administrative costs were covered since the current intake of learners were invariably based on the firms' needs. This raises the issue of marginal subsidies as a policy option (see example in section 3.3.2).

Anecdotal evidence presented by many of the respondents suggested that high start-up costs prevented many small firms from setting up and offering learnerships. Often large firms have one or two full-time staff members that are dedicated to dealing with SETAs and taking care of the administrative requirements related to learnerships. Smaller firms cannot afford such expenditures. The same goes for training providers: smaller training providers cannot afford to apply for accreditation and often lose out on training contracts because of this. Small firms play a very important role in creating employment opportunities, but the current learnership system is designed in such a way that it is difficult for smaller firms to participate.

Finally, at an institutional level many firms felt that better co-ordination and clarity was needed about the respective roles of the Departments of Labour and Education in the learnership system. Since learnerships involve both education and employment, areas of overlap require constant and consistent collaboration between the Department of Labour and the Department of Education, which many respondents felt was lacking.

Arising out of the above, some of the policy implications include:

- Exploring ways of simplifying the bureaucratic processes of the SETAs without compromising the credibility of the qualification obtained through a learnership. This is perhaps the greatest challenge and many feel that there is no real solution other than to give firms more responsibility and trusting them more in awarding qualifications. Simplification will also reduce costs, which will also allow greater buy-in from smaller firms.

- Reviewing the cost of providing training and education via a learnership programme by vesting administrative control and authority with registered education and training providers. The infrastructural and staffing requirements of learnerships offered at firms are enormous. Educational institutions perhaps have a competitive advantage in administering the process of assessing the academic performance of students and awarding qualifications. Firms should be allowed to focus on what they do better, namely provision of workplace training and practical experience.

12 Note that these figures may not be reliable averages across all industries and firms. 
- The fact that learnerships are linked to an academic qualification makes it a novel idea (transferability of a qualification across industries), but it also introduces administrative complexities (unit standards, assessment processes, accreditation etc.). 


\section{Box 2: The Letsema Learnership Programme}

In 2003 the Department of Labour (DoL) proposed that the banking sector place up to 10000 unemployed matriculants on learnerships per year. Subsequent discussions led to the sector undertaking to implement a learnership programme in terms of which "...each financial institution will employ up to 4.5 per cent of its total staff in the form of black matriculants, or the NQF level 4 equivalent, in registered learnerships" (Financial Sector Charter/FSC, paragraph 5.7). The result was the Letsema Learnership Project, which was launched in 2004. Letsema initially set out to enrol 5000 unemployed learners over a three-year period, made up of matriculants (75 per cent) and young graduates. In terms of the agreements in place, R211 million was earmarked for the project, with the DoL contributing R120 million from its National Skills Fund (NSF) and Bankseta providing the balance. Planned enrolments were as follows:

$\begin{array}{lccc} & \text { Letsemal (2004) } & \text { Letsema II (2005) } & \text { Letsema III (2006) } \\ \text { Matriculants } & 600 & 1200 & 1800 \\ \text { Graduates } & 200 & 400 & 600 \\ \text { SMME Learners } & 0 & 100 & 100 \\ \text { TOTAL } & 800 & 1700 & 2500\end{array}$

Letsema I commenced in March 2004 with 826 learners. The NSF contributed R20 million, while the Bankseta funded the remaining R26 million. However, in 2005, with no upfront funding from the NSF, only 813 learners (610 matriculants) were enrolled into Letsema II at a cost of R31 million (Bankseta). The NSF later contributed R15 million insisting this be used only for matriculants. Currently Letsema III only has 824 participants and only matriculants were enrolled due to cost considerations. The Bankseta provided R39 million for this phase, while no funding could be secured from the NSF. According to Mr Cas Coovadia of the Banking Council, indications are that the failure of the DoL to fulfil its commitments was not due to funding problems but rather due to a flawed bureaucratic process.

Despite the fact that the original target of 5000 learners will be missed by a significant margin, the project is still described by Mr Frank Groenewald, CEO of Bankseta, in a Business Report article as a "huge success". The programme has been well received by all the major banks who have indicated that they have the capacity to accommodate up to 1500 learners each, per year. The first two phases of Letsema are now complete, and more than 80 per cent of learners have been placed in permanent employment by the banks. Furthermore, according to officials at Bankseta, negotiations are currently underway for the induction of Letsema IV. Although nothing has been confirmed yet, the DoL will apparently contribute financially. An estimated R77 million has been earmarked for Letsema IV, which will commence in March 2007.

The Letsema Learnership Project is a large initiative with committed and enthusiastic stakeholders. The Bankseta, which was described by many respondents in the firm interviews as a very well run organisation, as well as the banking sector have shown commitment and intent to make a contribution towards reducing unemployment and improving skills among young matriculants and graduates. However, unfortunately it has also become an example of how bureaucratic processes, in this example, specifically those processes within the DoL, can hamper efforts to make a positive contribution. It is crucial that stakeholders in learnership programmes, in general, are not only committed, but that the administrative processes allow such initiatives to be successful. It is equally important that this initiative be monitored in future in order to ensure that targets are reached, especially given the prominence of the project in the National Skills Development Strategy.

Sources: Financial Sector Charter (www.treasury.gov.za), Sandra Dunn in Babb and Meyer (2005), Bankseta (www.bankseta.org.za and Ms Eva Tabane), Department of Labour (www.labour.gov.za), Business Report (www.busrep.co.za), Skills Portal (www.skillsportal.co.za), Mr Cas Coovadia of the Banking Council and Mr Sipho Ngidi of Standard Bank. 


\section{Box 3: Marginal Subsidies}

The notion of a marginal as opposed to an 'average' subsidy derives from the theory of employment or wage subsidies (see Pauw and Edwards, 2005). The learnership system falls in the same vein as employment subsidies in the sense that employment (in this case linked to training of the employee) is subsidised, which serves as an incentive to the employer to increase the overall employment level. If, however, firms collect the subsidy but fail to increase employment they receive a windfall gain and the subsidy is ineffective in reaching its goal of increased employment. This is in fact what seems to be happening with the learnership system: firms are collecting subsidies (or grants) for people that they probably would have hired and trained anyway (see section 3.3.2). This may be sample-specific: the firms that were interviewed are large firms and many have been involved in workplace training in any event. Kraak (2006) notes "training is occurring primarily in large and medium-sized firms enterprises that would train irrespective of incentives and encouragements from government". The author further finds that training expenditures range between 2 to 4 per cent of payroll, which is well above the sector charters' recommendation of around 1 per cent. "This was the case prior to the launch of the NSDS and continues to be the case today" (Kraak 2006)

During the interviews firms were asked whether, firstly, the current subsidy amount per learner covered costs, and secondly, how the subsidisation scheme would have to be changed to encourage them to increase the number of learners taken on annually. Most firms said that the subsidy amount approximately R25 000 at the start of the learnership and a further R25 000 upon completion did not cover costs, especially when taking into account hidden costs such as office space and equipment and staff time. Most firms also felt that they are currently training an optimum number of learners, which is typically based on staffing requirements, but if all administrative and training (direct and indirect) costs were covered, they would consider employing additional people.

A marginal subsidy in the context of an employment subsidy scheme works on the principle that only additional workers over and above the current employment level are subsidised (Pauw and Edwards 2005). This principle is easily adapted for the learnership system. Two variations of the model can be considered: (1) Rather than subsidising all trainees of the firm, only learners over and above the number of learners that would have been trained anyway are subsidised. (2) Alternatively, all learners are subsidised, but the subsidy amount for learners over and above some threshold level is higher.

\section{Examples:}

Firm A has 100 learners in year one and receives a subsidy of R25 000 for each learner. Government wishes to increase the number of learners at Firm A by 20 per cent to 120 learners. Firm A responds by saying they cannot absorb more, unless the total cost of the additional learners is covered (say R50 000 per learner). This subsidy now covers the marginal cost of employing an additional worker. This can become quite costly, and in order to finance the marginal subsidy government may consider reducing the 'average' subsidy of the first 100 learners. In the extreme the subsidy for the first can be reduced by 60 per cent to $R 15000$, in which case the R1 million that is saved can be used to subsidise 20 additional learners at $R 50000$ per learner. If it is really true that the firm would have trained the first 100 learners even in the absence of the subsidy, they will still train the 100 workers, but now also the additional 20 because the subsidy amount is now high enough to become an incentive to increase employment over and above the baseline intake.

While the above example is greatly simplified, it illustrates the point quite effectively. In reality the true marginal cost of employing an additional learner may be much lower given that significant investments have already been made to accommodate the first 100 learners. In instances where firms were able to provide estimates of the average cost per learner, figures ranged from about R35 000 (direct training and administrative expenses) to over R100 000 (cost of employment taking into account office space, equipment and staffing requirements, e.g. running a human resource division responsible for implementing and administering the learnership programme). The marginal cost per learner may be much lower, and probably closer to the R35 000 estimate (note that this is the net cost-to-company for a learner once the state subsidy and tax allowances are accounted for). 


\subsection{Vacancies, Scarce Skills, Education and Training}

\subsubsection{Identifying Scarce Skills}

Various types of shortages exist; in particular three main areas can be identified as critical:

- Shortage of artisans and other technically trained workers, such as electricians, technicians, mechanics etc. Engineers and scientists also listed high on the list of scarce skills. These shortages were especially raised as a concern in the manufacturing sectors.

- $\quad$ Shortage at middle- to senior-management level. This skills shortage exists within all industry types, e.g. mine managers or shaft managers in the mining industry, foremen and managing engineers in the manufacturing industry and general business managers in the services industry. Management skills, it seems, are so problematic that poaching is endemic across industries. For example, engineers and mine managers are often coaxed into accepting positions in the banking or finance industry.

- As far as entry-level positions are concerned, the constraint, as mentioned, is not necessarily the quantity of graduates, but rather the quality of these graduates. At the graduate level therefore the problem seems to relate to a skills deficit (in terms of quality) rather than a skills shortage (in terms of numbers).

The phenomenon of rising graduate unemployment has to be viewed within the context of skills shortages and vacancies that exist in the private sector. The third point above is interesting, as it suggests that graduate unemployment relates either to an oversupply of graduates in general or perhaps, more likely so, an oversupply of inappropriately qualified or poor quality graduates. Some firms explicitly noted that the average new recruit's education is of a lower quality than in the past, while others suggested that if they could find more good quality graduates they would increase the intake of graduates. This raises the issue of graduate employment targets, i.e. how many graduates would firms employ if there was no quality issue at hand?

The number of graduates absorbed intermittently by firms appears, in many cases, to be driven by the quality of supply. Hence, firms who require a set number of graduates may actually end up adjusting these targets downwards given the skills and quality of the pool of the applicants. Conversely, firms have indicated that they are willing and able to increase the intake if faced with a higher quality of labour supply. The notion, therefore, in an odd way, that supply creates its own demand, seems to be partially true at the margin here.

In section 3.4.2 we explore some of the reasons for the skills shortages as defined in the first two bullet-points above. We look at both the supply and demand-side issues that have contributed to this problem. Section 3.4.3 considers some of the concerns around the skills 
deficit problem and inadequate or inappropriate qualifications obtained by graduates at secondary and tertiary institutions.

\subsubsection{Explaining Skills Shortages}

\section{a. Graduation Levels in Technical Qualifications at Universities and Universities of Technology}

Kraak (2003) presents various figures showing evidence of declining numbers of engineering students graduating from tertiary institutions. For example, university graduates with engineering bachelor's degrees declined from a peak of just under 1600 in 1994 to around 1150 in 2000. Similarly, despite the almost fourfold increase in enrolments at universities of technology between 1988 and 2000, the number of students graduating with national diplomas, higher diplomas and degrees in engineering declined dramatically. As Kraak notes, "it is ironic that institutions of technology ... are currently witnessing a dramatic decline in a key 'hard' technology field (engineering), while graduations in 'softer' non-technical subjects (such as business studies) expand" (2003).

Adding further to the shortages is engineering graduates' unwillingness to do front-end engineering work, a problem identified by one of the construction firms interviewed. Most students show a strong preference for working as engineering consultants in a services environment rather than working at manufacturing plants or mines.

It is apparent that training at universities and universities of technology is skewed towards producing workers for the rapidly expanding tertiary (services) sector, with large numbers of students graduating in management sciences, commerce and finance. All this comes at the expense of the mining and manufacturing sectors. While such a shift towards services was perhaps justified by market conditions during the 1990s, manufacturing firms are currently facing skills shortages in the face of increasing demand for their products. Demand is fuelled further by government's plans to dramatically step up public sector investment in the next few years.

\section{b. Enrolment at Tertiary Educational Institutions}

Related to the above is the unique situation in the South African tertiary education system whereby a huge premium is placed on university educations as opposed to technical qualifications obtained at universities of technology, tertiary colleges or FET colleges. When compared to, for example, the United Kingdom, South Africa's enrolment at tertiary institutions appears to be highly skewed towards 'academic' institutions (universities and universities of technology) and away from FET colleges. Figure 1 shows clearly that South Africa has a large share of students attending universities and technikons relative to FET colleges. In 2001, the most recent year for which figures could be found, only 36.6 per cent of students attending 
a tertiary institution in the United Kingdom were attending a university or technikon, with the remainder (63.4 per cent) attending FET colleges. In the same year, attendance at tertiary institutions in South Africa was heavily skewed towards universities and technikons, with almost two-thirds of students attending universities or technikons. In that year 65.1 per cent of all tertiary students in South Africa were studying at universities or universities of technology. University students alone comprised 44 per cent of all students.

\section{Figure 1: Enrolment at Public Educational Institutions in South Africa and the United Kingdom}

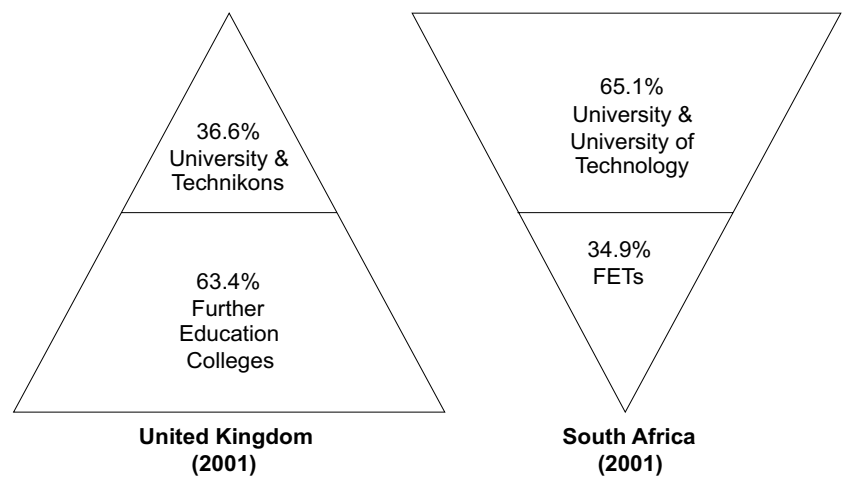

Source: (South African) Department of Education (2003) and UK Higher Education Statistics Agency (see www.hesa.co.uk).

Given the nature of skills shortages many firms felt that government should subsidise or promote tertiary enrolment in fields of study or training that are more practically orientated. Manufacturing firms, in particular, experience shortages of experienced artisans, which suggest that higher enrolment at technical FET colleges is crucial. Firms also called for greater collaboration between educational institutions and the business sector on curriculum design in order to address problems associated with irrelevance of certain course modules and the lack of practical application of theory. Collaboration entails developing courses together and creating opportunities for internships or experiential training as part of academic courses. It is crucial that the qualification and practical experience obtained at educational institutions are relevant to the needs of employers. 


\section{c. Workplace Training and the Policy Environment}

Adding to the current woes of the manufacturing sector is the apparent decline in apprenticeship training during the 1990s. Kraak (2003) shows that the number of apprentices in training in South Africa declined from 29826 in 1986 to 16577 in 1998, a drop of almost 50 per cent. A number of reasons exist for this decline, including economic reasons (contraction in output), as well as the policy environment. These are discussed further below.

This decline was driven by the contraction in output in the manufacturing sector over this period. Firms followed strategies of 'rightsizing' in an attempt to raise efficiency and reduce costs. Firms' expectations of future skills requirements were such that training did not feature high on the list of priorities for the sector. The lack of training provided can perhaps be seen as short-sighted by firms, although the recent boom phase and the planned increases in public sector investments could perhaps not have been foreseen at the time.

From 1998 onwards with the implementation of the Skills Development Act of 1998 (amended in 2003), which provided the institutional framework for the development and implementation of national, sectoral and workplace strategies to develop and improve the skills of the South African workforce, further uncertainties around the future of the apprenticeship system emerged. The Skills Development Act of 1998 effectively repealed the Manpower Training Act of 1981, which governed apprenticeships. However, schedule two in the Skills Development Act made provision for those sections in the Manpower Training Act pertaining to apprenticeships to remain in force until the Minister repealed them by notice in the Government Gazette. The Act, therefore, seemed to suggest that apprenticeships were being phased out and replaced with learnerships. Adding to these suspicions is the fact that learnerships have a much broader scope in terms of the coverage of occupations and, thus, in a sense encompass apprenticeships.

More recently various sectoral Black Economic Empowerment (BEE) charters were drawn up by the Sector Education and Training Authorities (SETAs), and very often the wording in these charters suggested that 'BEE points', which are awarded to firms to determine whether they are 'BEE compliant' only awarded points for learnerships specifically, and not apprenticeships. This has led some firms to convert apprenticeships to learnerships in order to comply with the BEE charters. In fact, some firms indicated that they only provide training based on the learnerships system because of the BEE points that are on offer. In the absence of learnerships they would have provided training based on their own models.

It appears now as if there is a realisation among policymakers that apprenticeships may perhaps be more appropriate. In fact, steps are being taken to 'bring back apprenticeships' and to restore firms faith in the future of apprenticeships. While the changeover from the apprenticeship to learnerships initially appeared to imply the end of apprenticeships, it now 
starts to seem that it was merely a name change. In an article published by The Skills Portal (TSP, 2006) the author reports on a statement by the Minister of Labour where he said he never repealed the sections in the Manpower Training Act that pertains to apprenticeships and further asked firms to "please take on apprentices" as this "the right thing to do". In addition most of the Sector and Education Authorities (SETAs) offer the same grants for learnerships and apprenticeships. According to officials at the Department of Labour the Department of Trade and Industry also recently proposed that learnerships and apprenticeships be awarded the same BEE points. Such a step will certainly remove all skewed incentives to implement learnerships over and above apprenticeships when the latter is in fact more appropriate for the firm concerned.

In summary, therefore, the economic circumstances (slow growth and uncertainties about the future) that prevailed during the 1990s, coupled with the uncertain policy environment regarding workplace training, probably led to a decline in the number of workers trained at the workplace.

\section{d. Middle-Management Training}

Despite the fact that firms cite skills shortages at middle-management level as a major concern, very few firms are using learnerships to offer subsidised training for middle-management level. Kraak (2003) presents figures from the Department of Labour for March 2002 showing the distribution of the number of registered learnerships programmes across different NQF levels. About 39 per cent of the programmes are targeted at NQF levels 1 to 3 (equivalent to prematriculation), while 47 per cent of programmes are targeted at NQF levels 4 and 5 (matric and matric plus diploma). The remainder (14 per cent) are for NQF levels 6 to 8 (equivalent to higher education degrees and postgraduate courses). In Figure 2 the 2002 estimates are compared with the latest figures from the Department of Labour (2006b). The figure shows a relative increase in the bias towards registering lower-level learnership programmes. ${ }^{13}$

In order to effectively address skills shortages at the mid-career level more subsidised learnerships programmes should be registered at the NQF 6 to 8 levels. This requires no change in the design of the learnership system - the system is already equipped to deal with higher-level learning. It merely requires changing the mindsets of training providers, firms and SETAs so that the learnership system is not only seen as entry-level training. It may even require a change in the mindset of employees, many of whom regard learnerships as beneath them. The various stakeholders, including SETAs, firms and educational institutions should

13 This may be due to the fact that the subsidies for unemployed learners are higher than those for employed learners, thus creating a bias towards enrolling unemployed learners onto lower NQF level learnerships. Perhaps a reconsideration of the incentive system is needed. Higher subsidies for NQF level learnerships where scarcities are most severe should perhaps be considered. 
work together towards developing and implementing suitable and appropriate higher-level learnership programmes that would gear firms towards training future managers.

Figure 2: Registered Learnership Programmes by NQF Category, 2002 and 2006

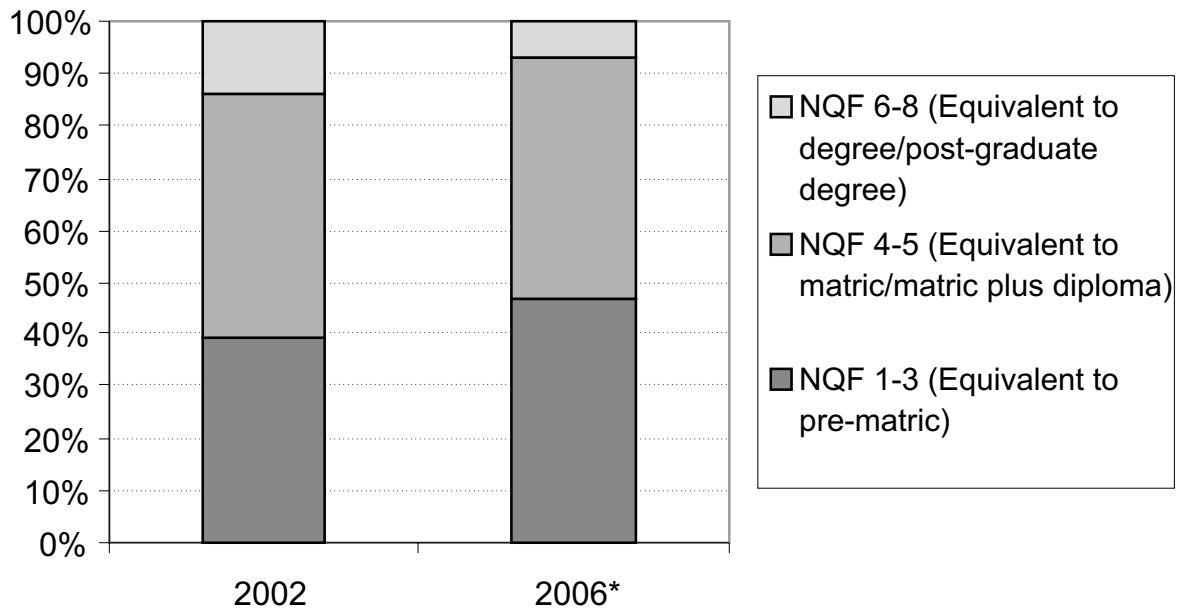

Source: Kraak (2003) and Department of Labour (2006b).

Note: $\quad$ These are the proportions of programmes registered, not learners. The figures for learners are not available at NQF level.

\section{e. Other Factors: The Brain Drain and Employment Equity}

The brain drain has also had a huge impact on manufacturing, construction and mining industries, especially in engineering-related fields. In an online article published by the South African Institution of Civil Engineering (Lawless, 2006) the author estimates that the industry had lost approximately 6000 educated and trained staff who have graduated since 1963. A "large percentage" has emigrated, while the rest have either taken early retirement or moved into other jobs. Ironically the author estimates that between 3000 and 6000 civil engineering professionals will be needed in the next few years to match the demand for skills driven by large projects such as Gautrain, the Soccer World Cup 2010, expansion at Eskom and Transnet.

Another interesting observation by Lawless (2006) is about the age distribution of civil engineering professionals in South Africa. It shows a large group of experienced engineers in their late forties and older. In contrast there are insufficient numbers of mid-career staff to carry out the bulk of production. The author notes that in the rest of the world, older, more experienced workers are being retained by raising the retirement age, while at the same time increasing the number of young people in training. Emigration and early retirement of 
experienced mid-career workers is certainly impacting on productivity and output in South Africa. A recent report published by Finweek (2006) suggested that 75 per cent of Eskom workers surveyed identified the staff shortages and inappropriate skills as the main reasons behind the electricity supply crisis. One of the banks interviewed mentioned specifically the huge problems they had with retaining experienced middle-management staff members, many of whom emigrate or set up their own businesses in South Africa.

\subsubsection{Explaining the Skills Deficit}

\section{a. Quality of Primary and Secondary Schooling}

The majority of firms identified low quality primary and secondary school education as a major factor behind the labour market problems in the South Africa. The poor quality of teachers and the low number of passes in matric mathematics and science was frequently raised as something that needs urgent attention. The transition from rural schools to tertiary education and the working environment is often daunting to people from disadvantaged backgrounds. This explains high drop-out rates at tertiary institutions, poor performance during formal job interviews and the inability of disadvantaged individuals to adapt to the working environment. Schools, and to large extent tertiary educational institutions, are also failing in the provision of proper career guidance despite well-publicised facts about poor job prospects for students studying in arts, humanities and the social sciences.

The quality of education needs to be addressed at a primary and secondary school level. School pupils need to be encouraged to follow mathematics and science as subjects. Career guidance councillors should educate them about the importance of these subjects. At the same time, the quality of teachers in these fields needs to be addressed through better training and remuneration packages.

In response to the slow progress in transforming and improving the schooling system, and especially mathematics and science teaching, a number of firms interviewed indicated that they are actively involved in school education. Firms invest in mathematics and science projects, while some fund learning centres, computer laboratories and so on. Firms view such initiatives not only as corporate social investments but also long-term investments in their own firms as they will benefit from an increased supply of matriculants with passes in suitable subjects. 


\section{b. Quality of FET Colleges}

The state of FET colleges, and particularly the quality of education and training provided at these institutions, is another concern. Some firms are of the opinion that the current FET system is not generating the quantity or quality of artisans that used to be produced under the old system of industry training boards. While major restructuring of the FET system has already taken place - recently 122 FET colleges were merged into 50 colleges, while a further R1.5 billion is being invested as part of the FET recapitalisation project - FET colleges have for too long been seen as ineffective and inefficient (Kraak 2003).

The South African FET system currently accommodates three types of FET colleges, namely the general academic FET, the vocational FET and the industry-based FET. The general academic FET's offer "a so-called 'whole' qualification consisting of exit level outcomes which schools will offer and which will no doubt form the basis for university entrance criteria" (Papier 2006: 6), while the vocational and industry-based FETs are more practically oriented. As with the move from apprenticeships to learnerships the college education system also appears to be moving away from a pure vocational training model to what some would term a more 'balanced' vocational and academic training model, driven by a need to educate people for the modern so-called 'knowledge-based learning society' (Papier 2006). There are two important issues here.

Firstly, broad education ensures inclusion in this knowledge society and deals to some extent with complaints from employers about young people that leave education without a balanced education that enables them to function in the workplace. However, the new vocational qualifications on the NQF may be a cause for concern for FET colleges who in the past have been training explicitly for industry. The additional educational requirements are potentially taking study and teaching time away from pure vocational training. As Papier suggests, "... it may well be that FET qualifications will again neither satisfy the demands of the workplace, nor the requirements of Higher Education" (2006: 6). The realities in South Africa are that young people need to acquire technical skills that would make them workplace ready and more employable, but at the same time softer skills are also lacking. This presents a major dilemma and challenge to the FET sector. Perhaps the greatest challenge to the FET sector is regaining the trust of industry.

A second is the quality issue. Many of the learnerships currently in place are being managed and run by private industry-based FET colleges. A number of firms interviewed indicated that they have gone the route of applying for accreditation as a training provider, either due to a lack of faith in the public education (FET) system, or because they felt that they could provide better quality and more appropriate training themselves. Smith et al. (2005: 559) find a similar trend among the sample of firms and learners interviewed by them "[d]espite massive efforts in South Africa to transform public ... FET colleges". Many of the large firms obviously have 
the capacity, economies of scale and experience to offer training. Whether this training can be offered at a lower cost than the cost of outsourcing the service is unclear. Either way, the perception of firms is that they can provide higher quality, more appropriate practical training than FET colleges that caters for a wide variety of firms.

\section{c. Quality of Education at Tertiary Institutions and Functional Illiteracy}

Another general concern relates to the quality of education offered at tertiary institutions. This, many felt, is driven by the strong focus on enrolling large numbers of students rather than focusing on the quality of education. Firms felt that educational subsidies at tertiary institutions should be based on a combination of student numbers and quality rating of the institution or the qualifications offered rather than the throughput rate as is presently the case. The current subsidisation system is creating the wrong incentives for educational institutions. It is also important that these institutions limit enrolment in degree or diploma courses with poor employment prospects. Poor academic performance of students (discussed in section 3.2) also relates to high functional illiteracy among students and poor soft skills. Tertiary educational institutions should focus on bringing soft skills, entrepreneurial skills and communication skills on board as part of bridging courses for students. 


\section{Box 4: Alternative Testing Methods for Graduates}

Much of the graduate unemployment problem is ascribed to the poor quality of education in South Africa. Qualifications obtained from historically black institutions especially are often deemed substandard, and as a result firms are reluctant to employ students from these institutions. Some respondents in the firm survey bluntly indicated that they had a complete distrust in qualifications awarded by certain institutions. This results in potentially good quality students from historically black institutions being overlooked. Many firms acknowledge that qualifications alone do not give an accurate representation of an employees potential. For example, poor English language skills sometimes prevent students from demonstrating their full potential. Other students may have difficult circumstances at home, perhaps having to support large families by working part-time, or living in an environment that is not conducive to learning. Thus, while some students have the potential to excel academically, they are unable to do so as measured by academic performance, and as a result the employer is unable to gauge the quality of the student.

Unfortunately an academic transcript is often the only information available to employers. Such information asymmetries generally lead to suboptimal outcomes. The idea of instituting some form of additional testing at a national level will do much to bridge the information deficiencies, while also removing firms' uncertainties about the comparability of qualifications from different institutions, many of which vary significantly in terms of quality, material covered or course contents, assessment methods and so on. The model used in the United States is perhaps a useful example. The Education Testing Service (ETS) offers a variety of tests. Although many of these are designed to be used by educational institutions in their decision to allow students to enrol in academic courses, they can also certainly be used by prospective employers to test the academic and even non-academic abilities of students.

Probably best known is the Standardised Aptitude Test (SAT), which consists of the Reasoning Test (measuring critical reading, math, and writing skills) and Subject Tests (measuring knowledge of particular subjects and the ability to apply that knowledge). Many colleges require or recommend one or more of these tests for admission or placement purposes. Also offered by ETS is the Graduate Record Examination (GRE), which is written by prospective graduate applicants and used by graduate admissions or fellowship panels to supplement undergraduate records and other qualifications. The scores provide common measures for comparing the qualifications of applicants. A general test measures critical thinking, analytical writing, verbal reasoning, and quantitative reasoning skills that have been acquired over a long period of time and that are not related to any specific field of study, while various subject-specific tests measure undergraduate achievement in the eight specific disciplines (Biochemistry, Cell and Molecular Biology; Biology; Chemistry; Computer Science; Literature in English; Mathematics; Physics; Psychology). Other tests offered by ETS include a test for Information and Communication Technology Literacy, a Measure of Academic Proficiency and Progress (MAPP), various tests of English and so on. Similarly, the Graduate Management Admission Council conducts a Graduate Management Admission Test (GMAT), which is a standardised assessment that helps business schools assess the qualifications of applicants for advanced study in business and management. Schools may use the test as a predictor of academic performance. The exam measures basic verbal, mathematical, and analytical writing skills developed over a long period of time in education and work. 


\section{Box 4: Continued...}

Various types of aptitude or psychometric tests have been developed that measure non-academic abilities, skills and personal profiles. Some firms may find it useful to draw on information about individuals' natural skills and abilities to operate within certain types of environments. For example, Solutionsfinding.com, a South African firm, has developed a variety of non-academic tests. Perhaps their best known instrument is the Neethling Brain Preference Profile (NBPP), which identifies the thinking preferences of the individual based on the "thinking quadrants" of the brain: analytical and factual, organised and detailed, interpersonal and sensitive, strategic and unorthodox. Linked to this are tests that identify personal skills (The Personal Skills Instrument), identify future skills needed for a specific career linked to an individual's preferences (The Future Skills Instrument), as well as a test that draws brain profiles for specific job types (The Job Skills Instrument). What makes these tests useful is that they can be performed on-line.

Testing of an academic nature has to be conducted and managed centrally by an independent organisation, but funded by the Department of Education. Non-academic tests must be based on accepted psychological practices. An idea put forward by one of the firms was that an institution such as the Umsobomvu Youth Fund (UYF), perhaps in conjunction with an institution with knowledge and experience in this area, becomes involved in testing of individuals that register on their database of unemployed youth. Given this institution's well-developed network of youth advisory centres with computer facilities across the country they are suitably equipped to conduct tests and register results on their database of unemployed youth. These results can complement matric results or transcripts of tertiary academic qualifications, thus making it easier for employers to make better-informed decisions about candidates.

Sources: US College Board (www.collegeboard.com), Educational Testing Service (www.ets.org), Graduate Management Admissions Council (www.mba.com), Solutionsfinding.com (www.solutionsfinding.com), Umsobomvu Youth Fund (www.youthportal.org.za). 


\section{Policy Options}

\subsection{On Skills Shortages and Vacancies}

\subsubsection{Immigration Service Centre}

Some of the short-term solutions proposed to deal with the skills scarcity problem include rehiring early retirees, assisting and encouraging South Africans living and working abroad to come back and sourcing foreigners with relevant scarce skills. The latter policy option has enjoyed the most media coverage in recent months. A scarce skills list published by the Department of Home Affairs in February 2006 contains 56 different occupation types and sets a quota of scarce skills that may be sourced from abroad at 46500 (Department of Home Affairs, 2006). Figure 3 shows how this quota is allocated across different broad occupation categories. Of these jobs, 55 per cent are in science and engineering, thus reflecting the critical shortages in this broad occupational category. Agricultural scientists make up 21 per cent of the total, while occupations in the health and medical sciences account for 11 per cent. The rest is distributed between people with Information Communication Technologies (ICT) skills (8 per cent), management and commerce skills (3 per cent) and the educational profession (2 per cent). The quotas are only applicable to foreigners with at least five years relevant experience. This ensures that the importation of skills does not impact on South Africans competing for entry-level positions (graduates).

An important provision attached to the sourcing of skills from abroad is that the foreign recruit should be employed in a position where he or she can act as a mentor or coach for young entry-level workers in the firm. Various other such scarce skills lists have been published recently, and a substantial literature exists around the methods used to identify scarce skills. These include lists by the Human Resources Development Council (2003), the National Advisory Council on Innovation and the Department of Science and Technology (2003) and the Human Science Research Council (2003) (surveyed by Powell and Groenmeyer-Edigheji, 2006). Most include engineers, artisans and technicians, while occupations such as educators and academics, scientists and biologists, and people with skills in the area of Information Communication Technology (ICT) are also prominent. 
Figure 3: Composition of Scarce Skills Quotas across Broad Occupation Categories

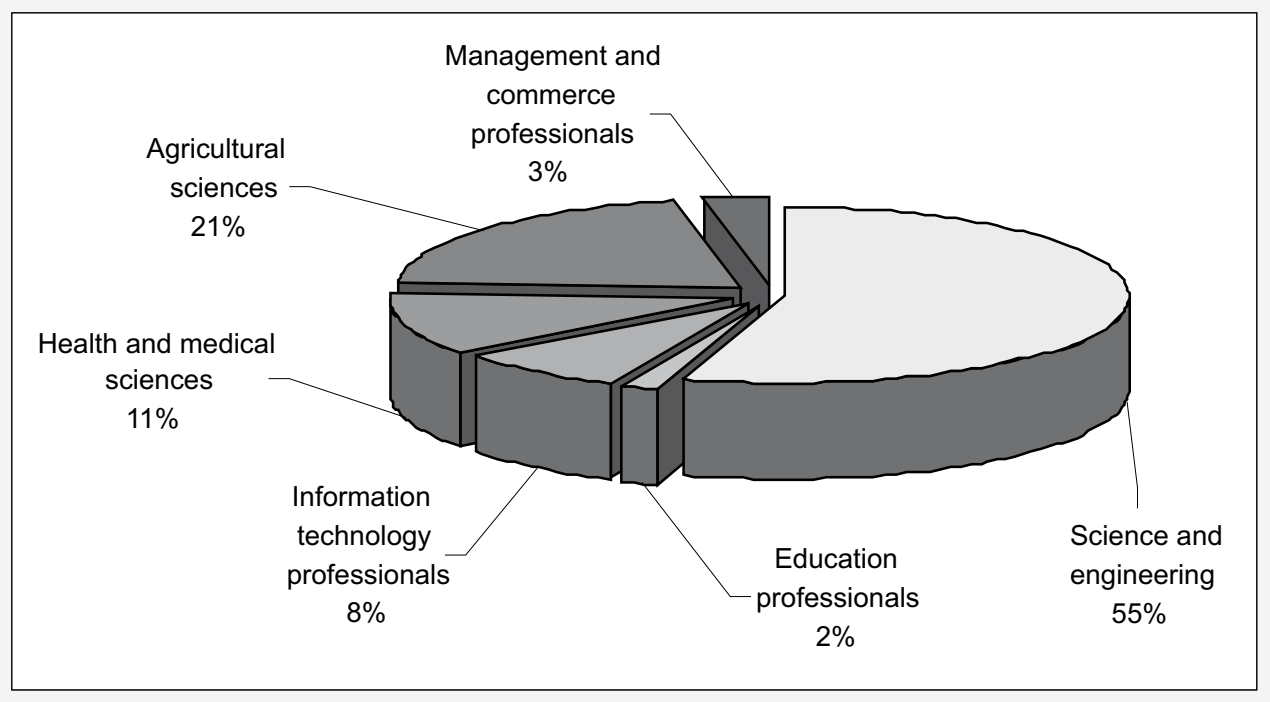

Source: Department of Home Affairs (2006).

The shortage of experienced, skilled employees, however defined, requires a bolder and more efficient immigration policy. Currently the turnaround time and associated bureaucratic inertia around immigrant worker applications makes this particular labour market intervention operationally inefficient. In addition, it remains a moot point whether the list identified by the Department of Home Affairs is in fact an exhaustive and accurate representation of skill shortages in the domestic economy. Given this we propose that an Immigration Service Centre for large, established companies be set up. In the first instance, to avoid second-guessing firms on their labour demand needs, it is proposed that the Department of Home Affairs list be viewed only as a guideline for skills in need. Secondly, in order to obviate the institutional inefficiency of such a centre, such an immigration service should guarantee the processing of all immigration paperwork within a month, with all due diligence around the specific occupation in need, being undertaken within this period.

\subsubsection{Middle-Management Training}

The sourcing of skills from abroad should be seen as a short-term measure to alleviate current shortages. In the longer run the ideal should be to train South Africans for these positions. At present learnerships are almost entirely focused on the lower NQF levels. This probably has to do with the fact that the NSDS is fairly explicit in suggesting that the unemployed youth are particularly vulnerable and, hence, a special target of the NSDS - as reflected in the higher subsidies for unemployed learners. 
As pointed out in section 3.4.2 the irony about workplace training is that despite the severe skills shortages at middle-management level, few firms are using learnerships to provide training at the higher NQF levels. In fact, as shown in Figure 2, the proportion of learnership programmes at the NQF 6 to 8 levels has actually declined since 2002. The learnership system is already equipped to deal with higher-level learning, and nothing prevents firms from utilising it as a way of providing subsidised training for skilled workers as well. As noted previously, the various stakeholders, including SETAs, firms and educational institutions should work together towards developing and implementing suitable and appropriate higher-level learnership programmes that would gear firms towards training future managers, and ultimately targeted at where the shortages currently exist.

\subsubsection{Restructuring and Marketing of FET Colleges}

A number of possible policy options regarding FET colleges present themselves. Hopefully these, together with the FET recapitalisation project, will be beneficial to standards and quality of training and education at FET colleges. This process should be monitored closely to ensure an optimal outcome. Some specific policy issues include:

- The move towards 'whole education' (see section 3.4.3) is driven by the need to ensure inclusion in the knowledge society, but it is also crucial that industry standards are met as far as firms' expectations of practical knowledge and experience is concerned. This requires a process of quality control as well as regular consultation with industry about the curricula at FET colleges.

- Support from industry is crucial. Many firms have applied for accreditation as training providers and opt to conduct learnerships and apprenticeships themselves rather than outsourcing this to FET colleges or other academic institutions. This is a reflection of the distrust of the private sector in public training at present, which poses a threat to the credibility and future of the FET system.

- Perhaps a 'soft' recommendation, but one we feel that is vital, revolves around the fact that FET colleges are viewed within the African community as a secondbest option for post-matric training. Hence, a key policy intervention would involve marketing FETs in African communities, and in particular repositioning them within these communities as institutions offering valuable and highly marketable skills. The severe shortage of artisans reported consistently by manufacturing firms, reinforces the need for this intervention. Corporate financial and logistical support could be considered for such a marketing campaign. 


\subsection{On Education and Human Capital}

\subsubsection{Addressing Poor Quality of School Outcomes}

Firms lamenting the poor quality of schooling leads to two short-term solutions, which we believe can be facilitated through JIPSA. These are:

- Greater funding of career guidance services that are offered either at schools or offsite. These will prove invaluable in inculcating the importance of mathematics and science amongst learners, which firms believed is not fully appreciated by young people.

- The restructuring of educators' remuneration packages (currently under negotiation between the DoE and SADTU) on the basis of scarce skills. Hence, we would expect that through such a reallocation, science and mathematics educators for example, would be remunerated more than other educators.

\subsubsection{Restructuring State Subsidies for Tertiary Institutions}

The mismatch between labour demand and supply as a function of problems with supply of labour through tertiary institutions is well-known. We propose the following short-term solutions:

- That the current state subsidy system, biased heavily in favour of throughputs, should be restructured to include a (regularly reviewed) ranking of the quality of the institution and an 'employability' criterion. Institutions ranked as high quality ones which, through their certification, manage to secure employment for most of their graduates, are therefore likely to attract the largest proportion of the subsidy.

- A special dispensation, outside of current funding envelopes, should be secured to support tertiary enrolment in areas where there are skills shortages. Again, employers should define where these shortages exist. 


\subsection{On Workplace Training}

\subsubsection{Increasing the Number of Learners}

The one substantive, and fairly unique, result to emerge from the survey is that in many cases firms are placing existing employees on learnerships. Put differently, learners are individuals that firms would have hired anyway or in fact have hired already. Hence, as an active labour market policy with the intention of inducing employment effects over-and-above market-driven increases, the learnership programme - at least from the evidence here and on this indicator - appears to have been unsuccessful.

We propose, again on the basis of suggestions from many of the firms, a more aggressive learnership programme that would in part:

- Increase the number of learners by 20 per cent from its current estimated annual figure of 43000 to approximately 51600 learners per annum. Many of the firms in the survey had indicated that they could possibly increase the number of learners, provided that the state covered all the costs of the additional learners.

- Hence, relatedly, we propose that the idea of a marginal subsidy is explored further as outlined and explained in Box 3 . The basic idea is that the state finances the marginal cost of taking additional learners over and above the current intake. This is based on the apparent assumption that the current value of the subsidy per learner does not act as an incentive to take on learners and, hence, learners represent people that would have been trained and employed in any event. A very rough figure indicates that the net cost-to-company for a learner (once the state subsidy and tax allowances are accounted for) is approximately R35000 per annum. Ultimately then, this would entail, admittedly on extremely rough figures, a total financial commitment of R300 million, which in the context of overall skills development budget ${ }^{14}$ falls within the expenditure limits (see Appendix $B$ ). It is clear that under the present conditions, where no 'above-equilibrium' employment is being generated, it may be an investment worth exploring.

14 R1.8 billion from the NSF alone is being allocated to SETAs for strategic community level projects and for unemployed learners in learnerships. This excludes R3.1 billion received by SETAs in skills development levies. 


\subsubsection{Reinstating Faith in Apprenticeship Training for Manufacturing}

As noted above, skills shortages at the entry or graduate level and those at the mid-career level are very different in nature. Many firms interviewed tended to agree that there are enough graduates coming through the education system, but that the quality of education and training is a concern. ${ }^{15}$ According to Smith et al. (2005: 540) South Africa, like many other countries including the United Kingdom (UK), Australia, Norway and New Zealand, based its learnerships system on a "reinvented notion of apprenticeships". Learnerships aim to provide workplace training by an accredited training provider by combining structured learning and workplace experience. The idea is that the training would culminate in a nationally recognised qualification.

While the main aim of learnerships is skills acquisition, it has also doubled up in South Africa as a type of employment or wage subsidy. The idea was that the financial incentives attached to learnerships would encourage firms to employ more workers, and that higher overall skill levels would increase the employability of workers in general, which would then indirectly lead to greater absorption. The perception among firms is that learnerships are (potentially) very effective in providing workers with the necessary skills and qualifications, with many firms indicating that their workers become more employable after completion of a learnership programme. However, given that a large number of firms simply put existing workers on learnerships, this suggests that learnerships are perhaps not as successful in terms of the absorption of more workers in the economy.

The adoption of learnerships, which, as explained earlier, initially seemed to imply the end of apprenticeships, introduced a lot of uncertainty about training in general. Workplace training for artisans and technicians was in the past based only on the apprenticeship system. The qualification attached to apprenticeship training is not necessarily SAQA accredited, which simply means that the qualification is not necessarily aligned with the 'transferable' NQF system. Qualifications are, however, generally recognised in respect of the specific trade. The training has a more practical focus and this is arguably more important given the nature of technical occupations. Learnerships actually incorporate artisan-type training, but are attached to a SAQA recognised academic qualification. This has some benefits to the trainee, including transferability and recognition of the qualification, but it also introduces an administrative burden to the firm, relating mostly to the requirements of the assessment process.

During the interviews a number of firms, especially those in the manufacturing and mining sectors, complained about the added administrative burden brought about by the academic requirements of learnerships. Firms feel that their core business competency is training, not

15 This may not necessarily be true for university or university of technology-trained engineers. However, it seems to hold for technical workers trained at FET colleges. 
assessing the academic merit of a candidate's qualification. The more academic or theoretical approach is certainly appropriate for many of the occupations that were not previously covered by apprenticeships. This is especially true for occupations in the services industries, e.g. call centre operators or accounting clerks. However, it is not always appropriate for artisan-type training.

The apparent realisation among policymakers (see section 3.4.2) that apprenticeships are in some instances more appropriate or preferred by firms is a step in the right direction. As mentioned before, steps are being taken to 'bring back apprenticeships' and to restore firms faith in the future of apprenticeships. These include an announcement by the Minister of Labour that firms should continue to enrol apprentices and that he has no intention of repealing the relevant section of Act. Also, proposals are being considered to give apprenticeships the same status as learnerships in terms of grants receivable from SETAs as well as BEE points awarded for training people. A clear policy standpoint needs to be taken on the issue, as years of training may already have been lost due to the uncertain policy environment surrounding workplace training. This does not mean that learnerships should now be abandoned again in favour of apprenticeships. Learnerships have their merits in certain types of environments, just as apprenticeships suit manufacturing firms with a strong focus on providing practical workplace training for artisans that do not necessarily need a SAQA accredited qualification. Instead therefore, what is required, is a clear signal from the Department of Labour and its respective SETAs, regarding the relationship between learnerships and apprenticeships, with a view to ensuring that firms are equally incentivised to invest in both learners and apprentices.

\subsubsection{Being Creative with Learnerships}

Many firms have benefited from applying learnerships in 'non-traditional' ways. The learnership system is a flexible system that can be adapted to any type of SAQA accredited qualification. Some examples include:

- Management-level learnerships (see previous discussions, sections 3.4 .2 and 4.1.2)

- $\quad$ Soft skills training (see section 3.3.3)

- Bridging courses to close the skills gap, e.g. accounting bridging courses and call centre or BPO courses (see section 3.3.3 and Box 1).

Not only do such creative applications address the graduate unemployment problem, but they may also solve many of the problems faced by employers with regards to middle-management vacancies, poor soft skills of graduates, and inappropriate qualifications among applicants. 


\subsection{Other Policy Issues}

\subsubsection{Promoting Bursary Schemes}

Bursary schemes are utilised by many larger firms either as a corporate social investment or as a core part of the recruitment process. We propose here that the state sets up a bursary scheme in conjunction with firms, that would subsidise any net additions to their current pool of bursars. Hence, firms would be incentivised to increase their existing quota of bursars, as these could potentially be funded by the state. The state could of course build its own criteria into such a firm-based bursary programme, ensuring that equity goals and employment guarantees are secured. Firm-based bursary schemes have a number of distinct advantages. Firstly, it locates labour demand needs directly with firms, ensuring effectively that the institutions of human capital are supplying the required skills to the labour market. Secondly, the firm can become involved more directly in the education of the student in the sense that they can provide academic support and guidance as to subject choice - something in this model that the state would not need to pay for. Thirdly, firms can offer relevant practical experience to bursary holders by creating opportunities for vacation work - an in-built work experience programme. Finally, all this comes at a fairly low risk to the company given the contractual obligations of the bursar to work for the firm on completion of his or her studies. If poached by another employer the bursar would have to pay back the bursary.

\subsubsection{Public Graduate Unemployment Databases}

The DPRU has managed to secure two databases of unemployed young people. The first, from the Umsobomvu Youth Fund (UYF), contains more than 130000 individuals (of which only about 81000 have supplied contact details), covering a wide spectrum of qualifications, including matric certificates, diplomas and degrees. The second database, is that provided by the South African Graduates Development Association (SAGDA), which contains a listing of some 2500 unemployed individuals with post-matriculation qualifications. Currently, both databases are in an electronic format that is not user-friendly to potential employers - a survey response that was common with respect to the UYF database in particular. However, these two datasets do contain the raw elements for a nationally representative electronic storage facility of unemployed individuals. This presently does not exist and, arguably, would serve as the beginning of a free service-based labour market information system for all firms in the economy (the full Report is available on the DPRU website at: http://www.commerce.uct.ac.za/ Research_Units/DPRU/OtherPDFs/Final_Graduate_Unemployment_Report.pdf 


\section{Conclusions}

A clear understanding of the nature and extent of vacancies or skills shortages in the economy may help us better understand the graduate unemployment problem. The South African manufacturing sector faces severe skills shortages in technical occupations such as artisans, engineers and scientists. In all sectors shortages of middle- to senior-management personnel was also raised as a concern. These shortages are viewed as critical constraints to accelerated growth in South Africa. The economy has entered a boom phase, fuelled by low inflation and interest rates, high real income levels and increased public investment expenditure. The danger is now that production cannot keep pace due to skills constraints, which may leave government's 6 per cent growth target a distant dream.

In addressing the shortages of skilled technicians, artisans, engineers and middle to senior management, government has proposed a policy whereby immigration laws and the work permit application process will be greatly simplified and relaxed in an effort to make it easier for people who possess critical skills to enter and work in South Africa. This is an important short- run initiative and if utilised properly by firms, may alleviate some of the most critical skills shortages in the short term. At the same time, however, it is equally important to curb the loss of critical skills through emigration with the use of aggressive retention strategies.

In the longer run it is to reinvest time and effort towards the development of new skills internally. The restructuring of the FET college system will hopefully improve the quality of technical training, although many have raised concerns about the new proposed curricula. Proper consultation between the authorities, educational institutions and industry may ensure that public education and training is appropriate and quality-driven. Workplace training in the form of learnerships and apprenticeships are generally viewed in a positive light by firms and should be expanded and improved even further. While there are some concerns around the efficiency and bureaucratic processes within the SETAs, it is important that firms buy into the process of training and developing internal talent. Various policy ideas around the implementation and use of learnerships and apprenticeships were raised in this report, including learnerships for middle-management training, options for creating incentives for firms to increase the intake of learners, and reinstating the faith in the apprenticeship system as an alternative to learnerships where appropriate. If the economy is successful in enrolling more learners it may potentially have a large impact on employment.

As far as graduate unemployment is concerned the problem has been identified as a skills deficit. Poor quality education, inappropriate qualifications and poor soft skills is causing firms to hire fewer graduates than they would have had the quality of these labour market entrants been higher. Reforms have to start at primary and secondary school level with proper education and good quality teachers, especially in the areas of mathematics and science. Career guidance and incentives to students (or academic institutions) to enrol in the right areas 
of study are crucial. Learnerships may also be used to close the skills gap, either through soft skills training or bridging courses that provide not only workplace readiness training, but also retrain graduates in the right study areas. While these are all measures to directly impact on graduate employment, or at least the employability of graduates, it is quite likely that graduate employment levels will also benefit indirectly from skills acquisition at middle to senior management level. Once fewer vacancies exist and management level firms will be able to absorb more graduates as well as skills and experience will be available for training of young recruits.

Ultimately then, the above study, through gleaning information from nationally representative statistics and a small, but significant sample of firms, has attempted an overview of the graduate unemployment issue. It is clear that in both our prognosis of the problem and a select, but hopefully, focused set of proposals much still needs to be done to resolve what is probably one of the key constraints to long-run growth in the South African economy. 


\section{References}

Department of Home Affairs (2006). "The National Scarce and Critical Skills List," Government Gazette, No. 28480.

Department of Labour (2006a). "National Skills Development Strategy (NSDS) Implementation Report: 2004 - 2005." Department of Labour, Pretoria. Available online at www.labour.gov.za. Unpublished.

Department of Labour (2006b). "Registered Learnerships by SETAs." Department of Labour, Pretoria. Available online at www.labour.gov.za. 27 January 2006.

Finweek (2006). "Eskom in for a skills shock," Finweek, posted 8 March 2006. Available online at www.fin24.co.za.

JSE/Liberty Life (2006). "JSE/Liberty Life Investment Challenge." Available online at http: //university.jse.co.za/Company/top40companies.htm. 10 March 2006.

Kraak, A. (2003). "HRD and the Skills Crisis." In Human Resources Development. Education, Employment and Skills in South Africa, edited by Kraak, A. and Perold, H. Pretoria: HSRC Press.

Kraak, A. (2006). "The challenge of the 'second economy' in South Africa: The contribution of skills development," Journal of Vocational Education and Training, 57(4): 429452.

Lawless, A. (2006). "Number \& Needs. A wake up call to address the capacity crisis in SA civil engineering," published online at www.civils.org.za. South African Institution of Civil Engineering.

National Treasury (2005). "Medium Term Budget Policy Statement." National Treasury, Pretoria. Available online at www.finance.gov.za. October 2005.

National Treasury (2006a). "Budget Review 2006." National Treasury, Pretoria. Available online at www.finance.gov.za

Papier, J. (2006). "FET Seminar: Youth Unemployment and Education in South Africa." Paper presented at the Harold Wolpe Memorial Trust and Inset Providers Coalition (IPC) 49th Open Dialogue Event., 2 February 2006, Cape Town.

Pauw, K. and Edwards, L. (2003). "Evaluating the General Equilibrium Effects of a Wage Subsidy Scheme for South Africa." Paper presented at the Biennial Conference of the Economic Society of South Africa, 17 - 19 September 2003, Somerset West.

Powell, L. and Groenmeyer-Edigheji, S. (2006). "The Identification of Scarce and Priority Skills. An Introduction to the Methodological and Conceptual Challenges Involved," Report prepared for the Accelerated and Shared Growth - South Africa (ASGISA) initiative. 6 February 2006. 
Republic of South Africa (1981). "Manpower Training Act, No. 56 of 1981." Pretoria.

Republic of South Africa (1998). "Skills Development Act, No. 97 of 1998." Pretoria.

Republic of South Africa (1999). “Skills Development Levies Act, No. 9 of 1999.” Pretoria.

Smith, M.J., Jennings, R. and Solanki, G. (2005). "Perspectives on Learnerships: a critique of South Africa's transformation of apprenticeships," Journal of Vocational Education and Training, 57(4): 539-564.

TSP (2006). "Apprenticeships are not dead,” The Skills Portal, posted 8 February 2006. Available online at www.skillsportal.co.za. 